\title{
Abnormal effect of strain rate on dynamic recrystallization of austenite in medium carbon steel alloyed by boron
}

\author{
T. V. Kniaziuk ${ }^{\dagger}$, A. A. Zisman \\ †npk3@crism.ru \\ National Research Center "Kurchatov Institute"-Central Research Institute of Structural Materials "Prometey", \\ St.-Petersburg, 191015, Russia
}

According to literature data confirmed by our experiments on various steels, the strain degree that triggers the dynamic recrystallization of austenite in high-temperature deformation increases with the strain rate. However, as shown in the present work, micro-alloying of medium carbon steel by boron results in the opposite dependence in the strain rate range of 1 to $100 \mathrm{~s}^{-1}$. The corresponding features of stress-strain diagrams comply with the former austenite structures revealed by chemical etching. A specific effect of boron is discussed with allowance for its segregations at grain boundaries where the recrystallization embryos form. Such segregations hinder rearrangement of atoms involved in the grain boundary migration and hence decelerate their bulging necessary to nucleate recrystallization origins. Similar to the known "yield tooth" effect, very strong strain hardening of the steel with boron eventually enables the boundaries to free from the segregated atoms and begin the dynamic recrystallization at relatively low strain degrees. The obtained results indicate that the considered phenomenon is not due to the ultimate strain rate as such but results from its combination with the boron alloying. The revealed regularities gain in significance for evident reasons. First, they enhance ductility of high-strength steels hot deformed with very high strain rates as, for instance, in case of hammering. Second, such treatments notably refine the austenite structure and, correspondingly, improve the transformed structure and final mechanical properties after steel quenching.

Keywords: austenite, hot deformation, dynamic recrystallization, boron, strain rate.

\section{Аномальное влияние скорости деформации на динамическую рекристаллизацию аустенита в борсодержащей среднеуглеродистой стали}

\author{
Князюк Т. В. ${ }^{\dagger}$, Зисман А. А. \\ Национальный Исследовательский Центр «Курчатовский Институт» - Центральный Научно-исследовательский \\ Институт Конструкционных Материалов «Прометей», Санкт-Петербург, 191015, Россия
}

Согласно многочисленным литературным данным, подтвержденным дополнительными экспериментами на различных сталях, с ростом скорости деформирования при высоких температурах увеличивается пороговая деформация, при которой начинается динамическая рекристаллизация аустенита. В то же время, как показано в данном исследовании, микролегирование среднеуглеродистой стали бором приводит к противоположной зависимости в диапазоне скоростей от 1 до $100 \mathrm{c}^{-1}$. Соответствующие особенности диаграмм деформирования согласуются с исходными структурами аустенита, выявленными с помощью химического травления. Специфический эффект растворенного в стали бора обсуждается с учетом его сегрегаций на границах зерен, где формируются зародыши рекристаллизации. Такие сегрегации препятствуют атомным перестроениям, обеспечивающим миграционную подвижность этих границ, замедляя их выгибание на локальных участках, с которыми связано зарождение рекристаллизации. Напоминая известный эффект «зуба текучести», сильное деформационное упрочнение стали с бором позволяет границам освободиться от сегрегаций и начать рекристаллизацию при относительно малых степенях деформации. Согласно полученным результатам, высокая скорость деформации сама по себе не вызывает рассматриваемую аномалию; ее необходимым условием также является легирование стали бором. Выявленные закономерности обладают практической значимостью по следующим очевидным причинам. Во-первых, быстрая динамическая рекристаллизация улучшает пластичность высокопрочных сталей при горячей деформации с предельно высокими скоростями как, например, при ковке на молотах. Во-вторых, подобная обработка существенно измельчает зерна аустенита и, соответственно, предопределяет благоприятную превращенную структуру и высокий уровень финальных механических свойств стали после закалки.

Ключевые слова: аустенит, горячая деформация, динамическая рекристаллизация, бор, скорость деформации. 


\section{Introduction}

The alloying of steels by boron is widely applied because this element suppresses the ferrite formation, and the resulting overcooling provides the driving force of martensitic transformation [1-5]. Such enhanced hardenability is ascribed to boron segregations in narrow zones at austenite grain boundaries [6-12] which presumably hinder rearrangements of atoms required for the phase transformation [13,14]. A specific influence of this element on the structure evolution of steel is also important in hot deformation of its parent phase [14-21]. Related effects particularly gain in significance in the hot forming at very high strain rates as, for instance, in case of hammering. However, to the authors' knowledge, this issue still does not attract a proper attention.

The present work has been motivated by our previous results [22] indicating an abnormal temperature dependence of the threshold strain that triggers the dynamic recrystallization (DR) of austenite in a medium carbon steel alloyed by boron and hot deformed at strain rates up to $100 \mathrm{~s}^{-1}$. Unlike the expected behavior, neither diminishing temperature nor increasing strain rate resulted in the growth of this characteristic. Thus, a question arises of whether such peculiarities of DR are due to the extreme strain rate as such or its combination with a specific effect of boron. To get an answer, we compare hot deformation behaviors of the abovementioned steel containing $0.003 \mathrm{wt} . \%$ of boron and several reference steels free of this element. The comparison is based on their stress-strain diagrams at temperatures of 950 to $1150^{\circ} \mathrm{C}$ and strain rates of 0.1 to $100 \mathrm{~s}^{-1}$. To confirm signs of abnormal DR found on such diagrams, respective austenite structures will be revealed by the chemical etching.

Following the common practice [23-25], the onset of DR will be specified by characteristic strain $e_{\mathrm{p}}$ that corresponds to a maximum $\left(\sigma_{\mathrm{p}}\right)$ of the deforming stress. Unlike critical strain $e_{\mathrm{c}}<e_{\mathrm{p}}$ indicating the very appearance of DR embryos, $e_{\mathrm{p}}$ approximately proportional to $e_{\mathrm{c}}$ [24] is much easier to derive from the stress-strain diagram. Moreover, since this parameter suggests a perceptible volume fraction of recrystallized grains, it can be verified by metallography. In addition, characteristic $e_{\mathrm{s}}>e_{\mathrm{p}}$ is also used to indicate the start of hardening that follows the pronounced softening by DR. Accordingly, $e_{\mathrm{s}}-e_{\mathrm{p}}$ roughly reflects a degree of DR on the strain scale. Such an expedient may be applied even if $\sigma_{p}$ is due to the stress stagnation (plateau) rather than its distinct peak.

\section{Materials and methods}

Quantities of alloying elements in the investigated materials are represented in Table 1. The first of them is austenitic steel; according to [26], DR of similar materials above $850^{\circ} \mathrm{C}$ mimics this phenomenon in austenite of low and medium carbon steels undergoing a phase transition in subsequent cooling. The second material is low carbon steel, whereas the third and fourth ones are medium carbon steels. The last of them, recently developed for agricultural applications [22], is alloyed by boron and displays abnormal properties as considered in the present work.

To determine peak strains $\varepsilon_{\mathrm{p}}$ indicating the onset of DR, cylindrical specimens $(10 \times 15 \mathrm{~mm})$ of these materials were compressed at strain rates of 0.1 to $100 \mathrm{~s}^{-1}$ at temperatures 950 , 1050 and $1150^{\circ} \mathrm{C}$ by means of thermo-mechanical simulator Gleeble-3800. To confirm DR peculiarities in B1500 derived from stress-strain diagrams, austenite grain boundaries in this steel have been revealed by etching in Marshall's reagent [27] at room temperature. Related structures have been analyzed on optical microscope Zeiss Axio Vert 40MAT.

\section{Results}

At moderate strain rates which do not exceed $1 \mathrm{~s}^{-1}$ both the reference (boron-free) steels and B1500 display an expected dependence of $e_{\mathrm{p}}$ on the deformation temperature. This is illustrated by stress-strain diagrams at $1 \mathrm{~s}^{-1}$ (Fig. 1) where diminishing temperature leads to an increase of $\varepsilon_{\mathrm{p}}$ or disappearance of the corresponding stress peak.

To reveal the effect of more rapid deformation, strain rates from 0.1 to $100 \mathrm{~s}^{-1}$ have been applied at a temperature of $1050^{\circ} \mathrm{C}$, intermediate between those considered above. As illustrated in Fig. 2, the reference materials in this case display the expected regular behavior, whereas stress peaks of steel B1500 remaining distinct on the diagrams suddenly drift to lower strains when increasing the strain rate from 1 to $100 \mathrm{~s}^{-1}$. At the same time, in the range of 0.1 to $1 \mathrm{~s}^{-1}$ this abnormal effect is not detected. It is worth noting as well that B1500 demonstrates the stronger work hardening before the DR onset.

To verify DR peculiarities of steel B1500, as indicated by its deformation behavior at high strain rates, Fig. 3 represents respective structures of hot deformed austenite revealed by the chemical etching. According to them, the DR is completed at $1 \mathrm{~s}^{-1}$ and involves almost the whole material at extreme strain rate of $100 \mathrm{~s}^{-1}$, whereas at $10 \mathrm{~s}^{-1}$ the volume fraction of recrystallized grains is relatively small. The considered structures roughly comply with related magnitudes of $e_{\mathrm{s}}-e_{\mathrm{p}}$ that evaluates the DR range on the strain scale. Indeed, unlike the minimum 0.15 at $10 \mathrm{~s}^{-1}$, this difference reaches about 0.40 and 0.60 at 1 and $100 \mathrm{~s}^{-1}$, respectively. However, a remark should be made that an accurate determination of $e_{\mathrm{p}}$ on the stress plateau in case of $1 \mathrm{~s}^{-1}$ is somewhat complicated.

\section{Concluding remarks}

To find out and quantify physical factors responsible for an abnormal dependence of DR threshold strain on the hot

Table 1. Fractions of alloying elements (wt.\%) in investigated steels.

\begin{tabular}{|c|c|c|c|c|c|c|c|c|c|c|}
\hline Steel & C & $\mathrm{Si}$ & $\mathrm{Ni}$ & $\mathrm{Mn}$ & $\mathrm{Cu}$ & $\mathrm{Cr}$ & Mo & V & $\mathrm{Nb}$ & B \\
\hline 316 & 0.08 & 0.6 & 10.05 & 1.5 & - & 15.5 & 2.0 & - & - & - \\
\hline S420 & 0.06 & 0.2 & 0.75 & 1.4 & 0.16 & 0.09 & 0.08 & 0.016 & 0.026 & - \\
\hline 30HGSA & 0.34 & 1.2 & 0.3 & 0.8 & 0.3 & 1.1 & - & - & - & - \\
\hline B1500 & 0.35 & 0.3 & \multicolumn{3}{|c|}{1.8 in total } & \multicolumn{2}{|c|}{0.75 in total } & 0.02 & 0.02 & 0.003 \\
\hline
\end{tabular}



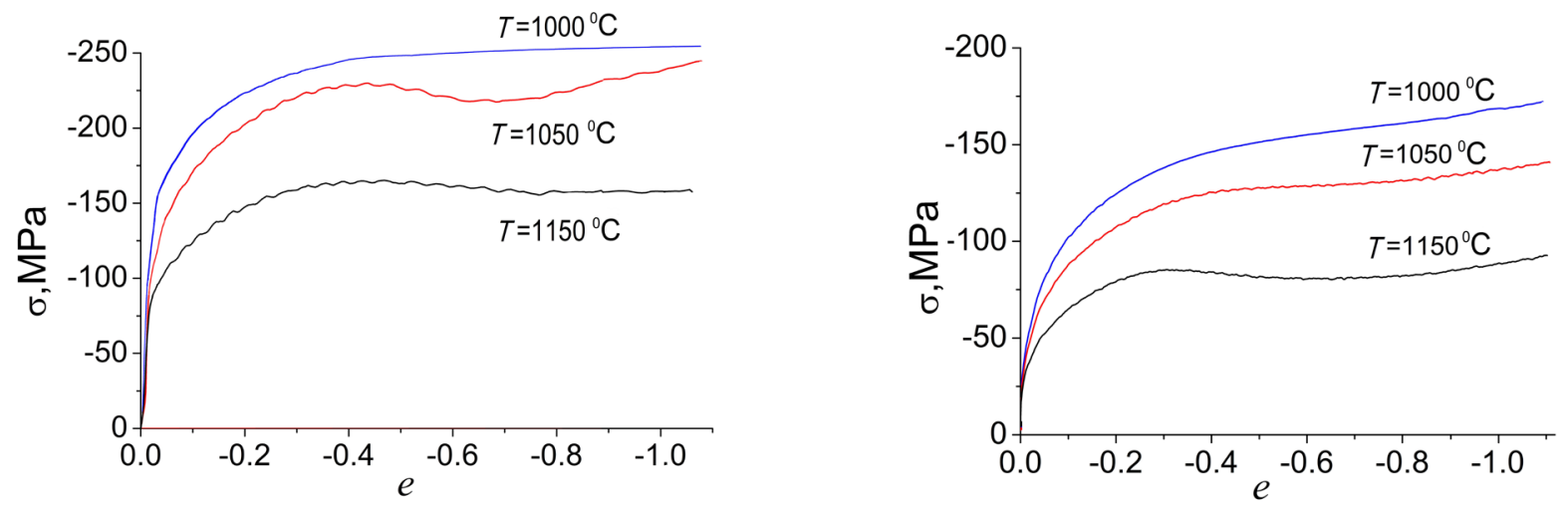

a
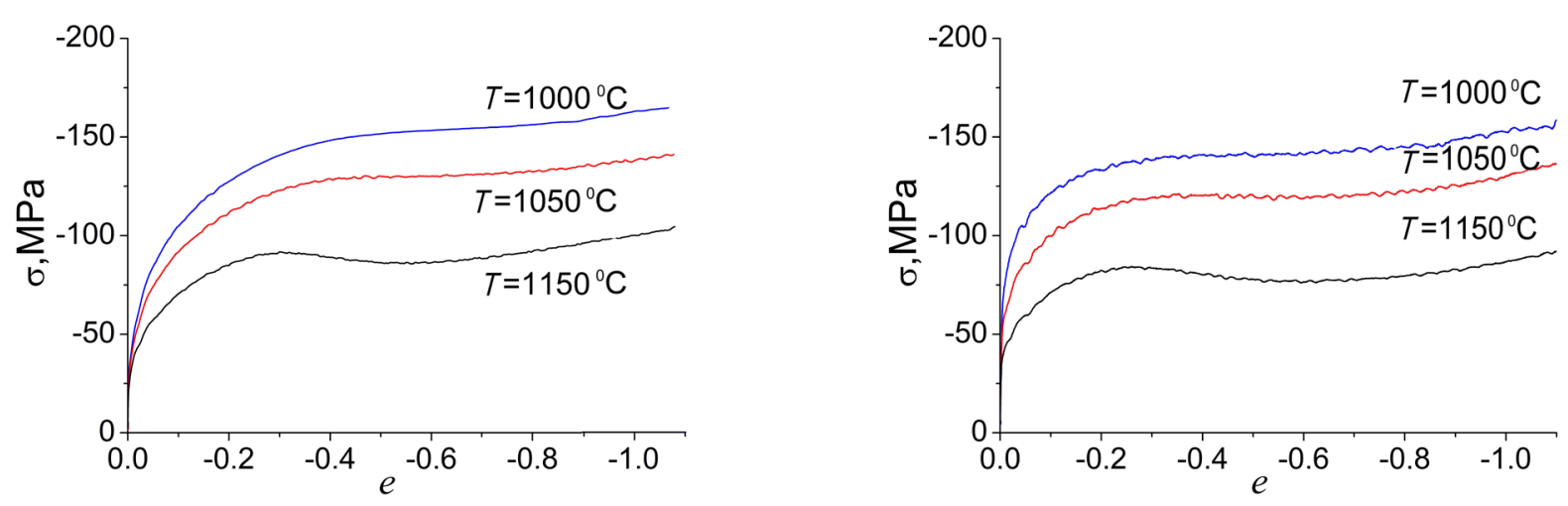

$\mathrm{d}$

Fig. 1. (Color online) Stress-strain diagrams at strain rate of $1 \mathrm{~s}^{-1}$ and various temperatures for steels 316 (a), S420 (b), $30 \mathrm{HGSA}$ (c), B1500 (d).

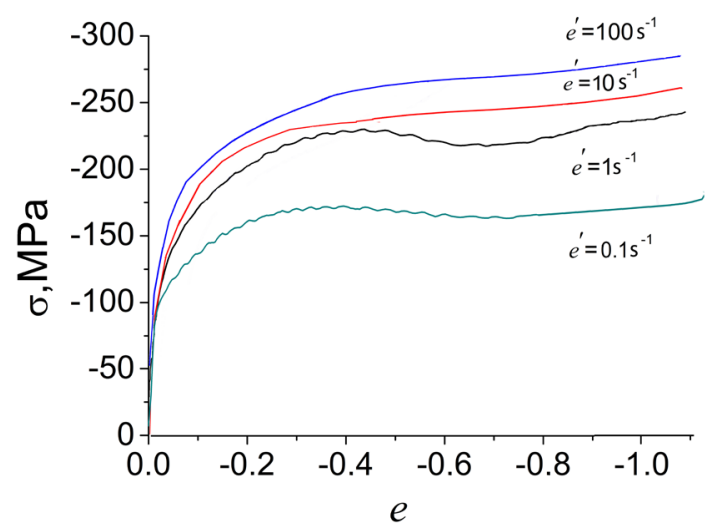

a

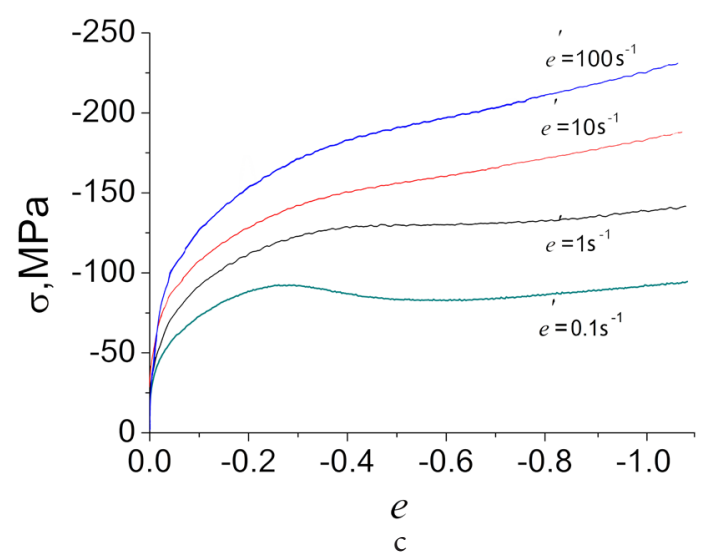

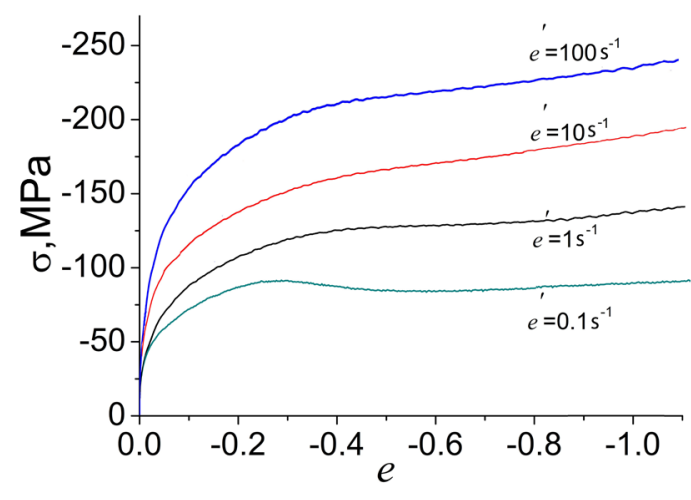

b

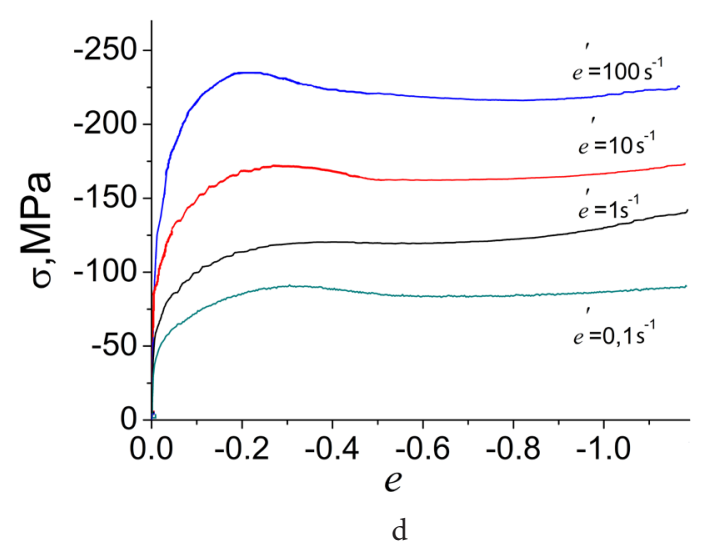

Fig. 2. (Color online) Stress-strain diagrams at a temperature of $1050^{\circ} \mathrm{C}$ and various strain rates of steels 316 (a), S420 (b), $30 \mathrm{HGSA}$ (c), B1500 (d). 


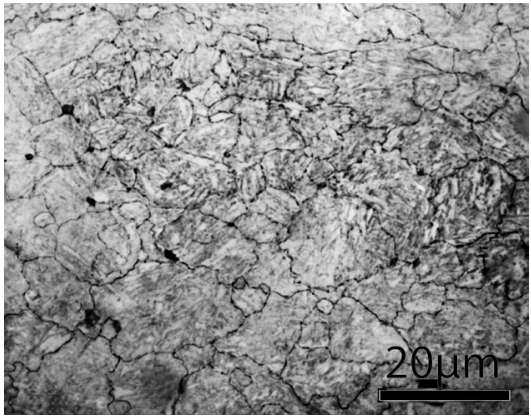

a

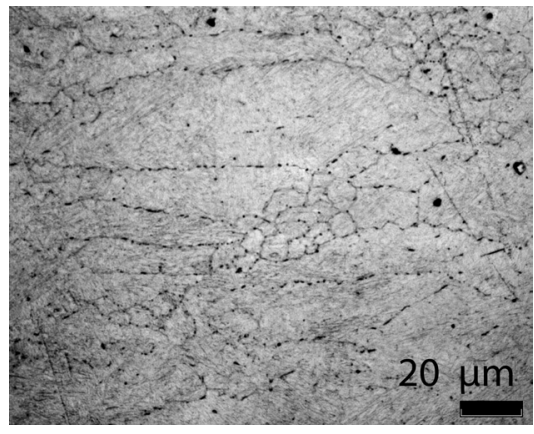

$\mathrm{b}$

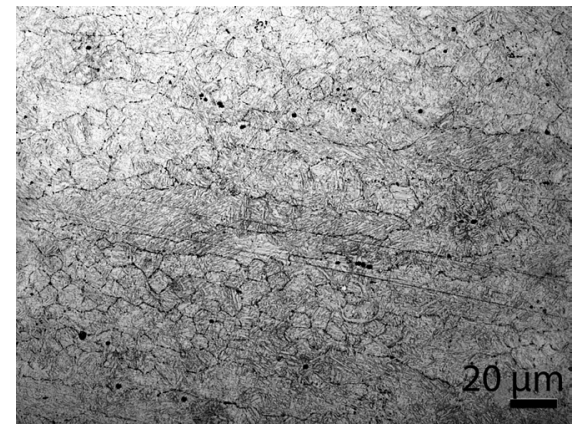

c

Fig. 3. Austenite structures of steel $\mathrm{B} 1500$ deformed at $1050^{\circ} \mathrm{C}$ with strain rates 1 (a), 10 (b) and $100 \mathrm{~s}^{-1}$ (c).

strain rate of steel B1500 is beyond the scope of the present experimental study. At the same time, when keeping in mind segregations of dissolved boron atoms at austenite grain boundaries $[3,4]$, a related qualitative explanation deserves discussion as follows.

According to the strong effect of this element on the steel hardenability, the considered segregations stabilize the crystal lattice of austenite and hence should also hinder the formation of its DR embryos. Specifically, boron atoms concentrated at grain boundaries reduce migratory mobility of the latter and thus should decelerate their local bulging that is an important mechanism of the DR nucleation [10]. However, intensification of the work hardening at higher strain rates of the steel with boron (Fig. $2 \mathrm{~d}$ ) results in a greater driving force of recrystallization that may eventually free the boundaries from the segregated atoms. The corresponding reduction of $e_{\mathrm{p}}$ will in a sense resemble the known effect of a sharp yield point due to atmospheres of interstitial atoms at the lattice dislocations.

The obtained results indicate that the considered phenomenon is not due to the ultimate strain rate as such but results from its combination with the boron alloying. The revealed regularities gain in significance for evident reasons. First, they enhance ductility of high-strength steels hot deformed with very high strain rates as, for instance, in case of hammering. Second, such treatments notably refine the austenite structure and, correspondingly, improve the transformed structure and final mechanical properties after steel quenching. As to further experimental investigations of the considered phenomenon, it would be advisable to compare steels whose chemical compositions are similar except for the varied boron fraction.

Acknowledgements. The authors thank A.A. Vasilyev, Associate Professor of the Institute of Physics and Mechanic Peter the Great SPbPU, for helpful discussions of this work. Experimental studies were carried out on the equipment of the Core shared research facilities "Composition, structure and properties of structural and functional materials" of the NRC "Kurchatov Institute" - CRISM "Prometey" with the financial support of the state represented by the Ministry of Education and Science of the Russian Federation under agreement No. 13.CKP.21.0014 (075-11-2021-068). The unique identifier is RF----2296.61321X0014

\section{References}

1. H.-R. Lin, G.-H. Cheng. Mater. Sci. Technol. 2, 855 (1987). Crossref

2. A. Terzic, M. Calcagnotto, S. Guk, T. Schulz, R. Kawalla. Mater. Sci. Eng. A. 584, 32 (2013). Crossref

3. J. Hannula, J. Kömi, D. A. Porter. Metall. Mater. Trans. 48, 5344 (2017). Crossref

4. B. Białobrzeska. Metals. 11, 589 (2021). Crossref

5. W. Elghazaly, R. Rashad, S. Elmohr, S. Elghazaly. Adv. in Mater. Sci. and Eng. 2016, 1203756 (2016). Crossref

6. L. Karlsson, H. Nordén. J. Physique. 47, 257 (1986). Crossref

7. L. Karlsson, H. Nordén, H. Odelius. Acta Metall. 36, 1 (1988). Crossref

8. G. Da Rosa, P. Maugis, A. Portavoce, J. Drillet, N. Valle, E. Lentzen, K. Hoummada. Acta Mater. 182, 226 (2020). Crossref

9. T. Osanai, N. Sekido, M. Yonemura, K. Maruyama, M. Takeuchi, K. Yoshimi. Mater. Char. 177, 111192 (2021). rossref

10. G. Dou, R. Cao, C. Cai, C. Han, X. Guo, Y. Jiang, J. Chen. Materials. 14, 926 (2021). Crossref

11. K. Luitjohan, M. Krane, D. Johnson. ISIJ International. 60, 92 (2020). $\underline{\text { Crossref }}$

12. A. Ahmadian, D. Scheiber, X. Zhou, B. Gault, C. H. Liebscher, L. Romaner, G. Dehm. Nat. Comm. 12, 6008 (2021). Crossref

13. T. Song, B. C. De Cooman. Metal. Mater. Trans. A. 44, 1686 (2013). Crossref

14. M. Jahazi, J. J. Jonas. Mater. Sci. Eng. A. 335, 49 (2002). Crossref

15. Y. Pei, X. Qu, Q. Ge, T. Wang. Materials. 14, 7110 (2021). Crossref

16. A. Gramlich, H. Schäfers, U. Krupp. Materials. 13, 5178 (2020). Crossref

17. Y. Zheng, F. Wang, C. Li, Z. Yang, Y. He. Mater. and Proc. 38, 380 (2019). Crossref

18. K. Ushioda. Science and Technology of Advanced Mater. 21, 29 (2020). Crossref

19. A. A. Vasilyev, D. F. Sokolov, S. F. Sokolov, A. A. Zisman, N.G. Kolbasnikov. Mater. Phys. Mech. 42, 609 (2019). Crossref

20. S.H. Song, A.M. Guo, D.D. Shen, Z.X. Yuan, J. Liu, T. D. Xu. Mater. Sci. Eng. A. 360, 96 (2003). 당s 
21. I. Mejía, G. Altamirano, A. Bedolla-Jacuinde, J. M. Cabrera, Mater. Sci. Eng. A. 610, 116 (2014). Crossref

22. T.V. Knyazyuk, A.A. Zisman, N.S. Novoskol'tsev, E. I. Khlusova. Phys. Met. Metallogr. 121, 543 (2020). Crossref

23. F. J. Humphreys, M. Hatherly. Recrystallization and related annealing phenomena. Amsterdam, Elsevier (2004) 574 p. $\underline{\text { Crossref }}$
24. A. I. Fernandez, P. Uranga, B. Lopez, J. M. RodriguezIbabe. Mater. Sci. Eng. A. 361, 367 (2003). Crossref

25. S. F. Medina, C. A. Hernandez. Acta Mater. 44, 137 (1996). Crossref

26. E. L. Brown, A. J. Deardo. Metall. Trans. A. 12, 39 (1981). Crossref

27. A. O. Benscoter, M. J. Perricone. Microsc. Microanal. 11, 76 (2005). $\underline{\text { Crossref }}$ 